European journal of American studies

\title{
Alcoholics Anonymous Comes to Poland: The Founding of the Polish AA and the American Connection
}

Marek Jannasz

\section{OpenEdition}

\section{Journals}

Electronic version

URL: https://journals.openedition.org/ejas/13694

DOI: $10.4000 /$ ejas. 13694

ISSN: 1991-9336

Publisher

European Association for American Studies

Electronic reference

Marek Jannasz, "Alcoholics Anonymous Comes to Poland: The Founding of the Polish AA and the American Connection", European journal of American studies [Online], 13-3 | 2018, Online since 07 January 2019, connection on 08 July 2021. URL: http://journals.openedition.org/ejas/13694 ; DOI: https://doi.org/10.4000/ejas.13694

This text was automatically generated on 8 July 2021 .

Creative Commons License 


\title{
Alcoholics Anonymous Comes to Poland: The Founding of the Polish $\mathrm{AA}$ and the American Connection
}

\author{
Marek Jannasz
}

\section{Introduction}

1 In May 2018, the manuscript of the Alcoholics Anonymous Big Book was purchased at auction for over two million dollars by Jim Irsay, an American billionaire who promised to create a special place in New York to exhibit it in public for visitors from across the world. On this occasion, Joe Maddalena, the founder of a renowned auction house, said: "We are thrilled this most historic manuscript has sold and hope it will be exhibited for the world to see the manuscript that has saved the lives of millions of people" (Associated Press, May 5, 2018, www.apnews.com). Quoted after the Associated Press, the press release, which also became the news of the day at Yahoo.com, reveals something important about the American heritage of the AA fellowship, its social significance and worldwide spread, as well as the media recognition of its success. It shows the reasons why it is worthwhile, according to the author of this paper, to discuss the issue of the 12-steps movement as a social and cultural phenomenon initiated in the American society and then imported by communities across the worldamong others by the Poles-despite many differences and barriers. This importation, however, did not occur automatically or painlessly: it was a process which transformed both the fellowship itself and the local social worlds.

2 This article proposes to investigate the work of AA in Poland, placing this American invention in a comparative international context and tracing the process of its cultural adaptation to foreign realities. It is part of a planned volume-length study, in which the author has drawn on a number of methodologies and sources, including in-depth interviews with AA fellows and some of the most prominent individuals involved in introducing AA to Poland in the 1970s and 1980s, as well as with a number of American 
AA fellows and administrators who supported them in this effort. The study hopes to fill a visible gap persisting in the AA research, which has mostly concentrated on the therapeutic aspects of the 12-step movements, leaving aside the (inter)cultural aspects of their international expansion. Such a new focus should also allow some insights into the processes of so-called Americanization, or more specifically of cultural and institutional transfers stemming from the United States and comprising the global flow of culture. The first part of this article will provide a brief historical outline of the 12step movement and reconsider its claim to be an outgrowth of so-called "Americanization." The second part will consist of the history of the AA movement in Poland, followed by observations on the adaptability of that American phenomenon in a foreign country and the role played by cultural difference in the adaptation process.

\section{American Roots, Global Development}

\subsection{Alcoholics Anonymous as an American Invention? A Deconstruction of the Myth}

3 It is commonly believed that mutual help movements based on the 12-step program, with the Alcoholics Anonymous in particular, originate from the United States of America. This statement finds its grounds in the historical facts surrounding the foundation of AA, in particular its time and place, i.e. the meeting of Bill W. and Doctor Bob, the "creators" or "founding fathers" of AA, which took place in Akron, Ohio, in 1935. That meeting was to become a founding myth of AA, the latter sharing striking resemblances with other myths drawing on the traditional repertoire of American exceptionalism (Lipset 19-70). As a matter of fact this fascination with AA as a deeply American cultural and social phenomenon is a recurring pattern in many writings on the history of the movement. Some European researchers, for example, tend to idealize the AA in opposition to other forms of so-called Americanization: "American culture has often been actively exported or promoted by centralized organizations. In contrast, there are no military, political, commercial, or even national cultural interests connected with the spread of AA" (Makela, et al. 29).

\subsubsection{Once Upon a Time in America}

4 In May 1935, Willian G. Wilson (in AA known as Bill W.), a sobering alcoholic and a New York broker travelling on business to Akron, Ohio, met Robert Holbrook Smith (aka "Doctor Bob"), a surgeon and also an alcoholic. At that time, Bill W. has just given up drinking to become a sober man and shared his personal experience with his alcoholic companion who had been suffering from the addiction and trying to fight it for quite some time. "1935, June 10: Dr. Bob has his last drink. Alcoholics Anonymous founded" notes one of the key AA texts: Alcoholics Anonymous Comes of Age (Alcoholics Anonymous Comes of Age, p. vii).

5 There is no reason to doubt the historical authenticity of this event. At the same time, given all the spoken and written tradition inspired by this encounter, it also seems to be mythical. In reality, when it actually happened, it appeared rather ordinary, as it usually happens with any mythical beginnings. At the time when it happened, no one 
could have foreseen the birth of the AA movement, let alone its global spread that followed.

Beginning in 1935, two founding fathers started assisting other fellow-alcoholics and drew up a mutual help program to overcome the addition. This was based on meetings with other alcoholics and sharing experience as well as nurturing spiritual development. The first piece of information concerning this program dates back to 1939. It appeared in a publication entitled Alcoholics Anonymous which serves as something of a Bible for any AA member, also known as "The Big Book" (Alcoholics Anonymous. New York, 1st edition 1939) due to its normative nature (despite the fact that it is a rather modest booklet). After overcoming the initial hurdles typical of any newly founded movement, AA managed to spread quickly in the United States during and following the Second World War, and later also overseas. This story was described in detail by Kurtz and other AA historians (e.g. Kurtz). Before the twenty-first century, Alcoholics Anonymous had about 2 million members associated in about 110,000 groups in almost every country or territory across the world.

7 The origins of the AA reveal some distinctive features which are typical of the manner in which the 12-step movements reached self-identification: (1) A meeting of two strangers is, by its very definition, very private and individualistic. (2) Its success-Dr. Bob's recovery-was achieved without any additional external support. (3) For both founders, the idea of sharing their experience with the fellowship is very natural and, at the same time, ethical. (4) From the very beginning their activities are fully voluntary: AA members freely choose to share their experience with other, still suffering fellow-alcoholics. (5) The activities of the AA founders are based on spiritual ideas, quite similar to certain well-known Protestant movements and religious concepts such as that of redemption.

One should note that the features no. (4) and (5) reveal themselves as a double-edged sword (to use Lipset's phrase from his book on American exceptionalism) since by promoting individual initiative and voluntarism, they at the same time present a threat to the coherence of the communitarian nature of the movement. Yet the AA through its activity (it is not an organization but a fellowship par excellence) seems to be offering a solution to the contradictory claims of individualism vs. collectiveness, and it does so in a manner which could serve as an example for other movements, grass-roots initiatives, etc. This was even admitted by one of the distinguished critics of AA: "AA, owing largely to Bill Wilson, has developed an organizational structure which is completely noncoercive and very democratic, and is in fact quite similar to organizational models developed by anarchist theorists" (Bufe 59-60).

Despite its virtually anarchistic structure, AA remains very successful proving at the same time that it is possible to defy the so called "tyranny of structure": even in the period of dramatic increase in the number of members and substantial spread of its reach, AA managed to retain its original character as a community of small groups of fellow-alcoholics gathering locally in weekly meetings.

10 One should note that the AA's global reach seems to be partly tied to its identification abroad as an American invention. In the research conducted by Makela and his mainly European co-editors, there are comments which directly indicate that AA is an American phenomenon, created in the United States, invented by representatives of American (mainly Anglo-Saxon middle class) and undoubtedly rooted in its traditions and Protestantism. At the same time, the research shows how successfully this Anglo- 
Saxon phenomenon became adapted to other cultures or communities like Catholic Mexicans or the native Canadian Inuit (Makela 27).

\subsubsection{Religion, individualism, pragmatism}

11 It seems clear that any discussion of the uniqueness of AA as an American invention may not fail to take into account religion, individualism and pragmatism. Therefore, they deserve more attention and will be discussed separately below.

Starting with religion seems to be quite obvious when we realize that from the technical point of view AA began in Akron not only as a private meeting of two alcoholics (the founding myth about AA as an "invention"), but at the same time as a part of religious activities in a local community. As a matter of fact one may argue that it took an initial organizational shape as a small adjacent group within religious Oxford Groups Movement. From the very beginning mutual-help groups received encouragement first of all from Protestant religious organizations, a fact well-known to AA historians and sociologists of religion, like Robert Wuthnow. In his Sharing the Journey: Support Groups and the Quest for a New Community, Wuthnow observes that starting from its origins Alcoholics Anonymous was deeply influenced by religious teachings, having its roots in the so-called Oxford Groups movement (113). For our thesis let us just indicate three main attributes of the Oxford Groups that were directly borrowed by early AA and that at the same time could be perceived as very "American" (Kurtz 47-48; Wuthnow 113; Bufe 57-62): 1) informal community gatherings of "house parties" typical for Protestant tradition, with religion as a "members-friendly" form of fellowship; 2) members or participants not expected to leave their own churches (a tolerance characteristic of American Christianity, rare in Roman Catholic countries); 3) focus on self-development and transforming one's life attained by passing through stages (adopted in 12-steps approach of the AA program). To this "technical list" of religious borrowings in AA teaching one may also add some features traditionally identified as an "American" way of solving social problems (Bufe 60): 1) antiintellectualism; 2) a strong belief in individual redemption; 3) focus on the individual's own story, not on one's background or faith (individualism and tolerance again).

These features became fundamental to the key practices of Alcoholics Anonymous meetings like: individual "story-telling"; strict rules forbidding direct criticism; equality of all speakers and participants; and "giving an example" as the main way of promoting AA ideas. However, AA quickly separated from the Oxford Group movement, mainly because of a profound difference in aims. The Oxford Group aimed to convert the world, while the AA has been focused from its mythical origins on helping individual alcoholics, with no ambition to improve the world or even enlighten society as far as addictions are concerned. While religion has played an important role in AA since its first meetings, consistently with its own mythicized perception of "the" American tradition the 12-steps fellowship embraces a mixture of devotion with pragmatism, individualism with community values, and effectiveness with distrust for organized religions. This distrust is understandable realizing that AA was invented by members of so-called wet generation, people disappointed after the First World War by nineteenth century Victorian morality:

part of the revolt of the 'wet generations' had been against organized religion. While the heart of the Alcoholics Anonymous experience was religious, this aspect was kept noninstitutionalized and was softpedaled and attenuated as far as 
possible. In this way an AA recruit could tiptoe through the minefield of the anticlerical commitments of his or her youth while recapturing a sense of purpose beyond the individual ego. (Room 381) sense). The Third Tradition of the AA says: "The only requirement for membership is an honest desire to stop drinking" (Twelve steps and Twelve Traditions 21). It means that the A.A. membership could never be under the control of any other person. During the early days of the AA this "liberal" approach created some organizational problems and the desire to resolve them by imposing strict rules and strengthening stiff structure. Fortunately, as it appeared in next decades, the first AA generation succeeded in overcoming the initial difficulties remaining immune to the tempting visions of a big, centralized organization. This kind of anti-authoritarian and anti-organizational thinking took an anecdotic name of "Rule No. 62": "Don't take yourself too damned seriously" (Alcoholics Anonymous Comes of Age 104), which is a quotation from the laconic response of Bill W. to a draft of 61 rules proposed by one of local AA groups (see Kurtz 108).

17 For the early days of AA the key factor attracting newcomers was neither spirituality and the idea of "higher power," nor an individualistic approach and organizational uniqueness, but the simple fact that it worked. It worked in terms of helping alcoholics in quitting their addiction and staying "dry." It is no coincidence that the key fifth chapter of the Big Book, the AA "Bible" mentioned above, is entitled "How It Works" (Alcoholics Anonymous 49). This pragmatic statement has been kept from the beginning as the fundamental message of Alcoholics Anonymous to its members and members to be. The AA pragmatism meant, among other things, the sharing of successful stories of redemption with happy endings. But pragmatism also meant openness and tolerance: "A small group may combine a dozen people from a dozen different religious 
backgrounds. They very likely will be unable to agree on specific religious doctrines or theological arguments. What they can agree on is that God helped them through" (Wuthnow 19). ${ }^{1}$

\subsection{Globalization of AA}

18 The global success of the 12-step movement and the therapeutic methods based on its principles seems to be an indisputable fact recognized by scientists and researchers who deal with this topic. American culture and social institutions have frequently been exported by centralized organizations funded by the government or big business. There are, however, no political, business or national interests which could be directly linked to the spread of AA (Makela 29). This model of grass-roots expansionism perfectly corresponds with the myth of the AA as an "American" invention and the earlier mentioned concepts like individualism or pragmatism-the ideas which embody the self-organizing genius of the community which functions despite (or, as in the case of Poland in the 1980s-against) the authorities. This is the case because "however dogmatic... an AA group could become, any two or three fellow alcoholics who object the way things have been going could leave it and start meeting for sobriety elsewhere creating their own, new AA group" (Kurtz 16).

The universal benefits of the organizational model of the 12 step movement are recognized even by the above mentioned critics of AA: "many of AA's useful features, particularly its organizational principles and structure, could be fruitfully adopted in a far wider social and political sphere than that of alcoholism self-help groups" (Bufe 4). Among the different types of small associations, the mutual help groups belong to the most democratic and least dependent organizations, being most capable of working without strong leaders despite the fact that they often function with the organizational support of various churches. Robert Wuthnow, quoted above, appears to be right claiming that "small groups attract people not because of their organizational structure but because of the fact that these groups seem cozy, friendly and informal" (Wuthnow 121). Even more importantly, despite the efforts made by the clergy of a number of denominations who aimed to control what was going on in groups associated with churches, their members generally exercised a great deal of autonomy. This autonomy was also seen in the case of the Polish AA (Tadeusz AA, 194-247), where it was achieved despite the culturally unique role of the Catholic Church. The study of the Polish AA with its grassroots strategy seems especially pertinent, as it points towards a larger cultural and social context of Eastern Europe with its historical deficiency of social capital (see Marek Ziółkowski's introduction to the Polish edition of Bowling Alone: Putnam 18-19).

\subsection{The Case of Poland}

The idea of the fellowship of alcoholics and their mutual help came to Poland in the 1950s, and the 1980s mark the beginning of its rapid expansion. According to the common opinion of the researchers and founders of the Polish AA, this became possible by means of importing this American invention directly from the United States (see Osiatyński 32-40). The roots of the Polish AA were untypical, however, because from the very beginning it was greatly aided by professionals-therapists who not only assisted in its organization, but also took part in the meetings. The Polish mutual help 
movement was also subject to institutional pressures which came from, on the one hand, the communist government with its Abstainers Clubs and information control, and on the other hand the Catholic Church which extended material assistance but tried to control the movement at the same time. However, according to the testimonials (notes from my conversations with Wiktor Osiatyński, February 2015January 2017; my interview with Robert D. Gamble, Poznań, May 2018), as well as the Polish and American books on AA (Kurtz 158-162; Dumanowski 12-19), those difficulties were eventually overcome and the American model prevailed. This can be used to illustrate the power of the values described above constituting part of the American AA tradition. Before AA, groups such as these had been something unheard of in Poland. Subsequently, they went on to grow becoming mass-movements in a matter of several years and without any official support, without any funding with taxpayers' money and in a way that-to employ some clichés-was rather American than European.

By no means, however, does the above relieve a researcher from a critical deconstruction of the myths connected with the American origins of the 12-step movements and their global success. To this end, the importation of AA to Poland as a cultural and social phenomenon is analyzed below.

\section{The Origins of AA in Poland}

\subsection{Two Beginnings, Two Centers}

It can be rather difficult to identify one specific event as the actual beginning of the Polish AA. We're actually looking at two distinct beginnings and two different centers: one in Poznan in the 1950s and 1960s and the other one in Warsaw in the 1980s (see Tadeusz AA). The dispute over the significance of the two centers can be perceived as a contest for recognition of the "true" birthplace of the Polish AA. This transpires from the statements of the "founding fathers" upon comparison of the records from Poznan (interview with TT, Poznan April, 2017, the $1^{\text {st }}$ interview with Robert Gamble. Warsaw June 2016) with those originating from Warsaw (interview with FD, Warsaw January 2017, interview with Bohdan Woronowicz, Warsaw, February 2017) and also Cracow (interview with TF, Cracow October 2017). ${ }^{2}$ The last of the above statements, coming from a Cracow activist, best describes the issue, perhaps due to his neutral attitude to the other centers: "Everyone was looking for an effective way to get rid of the habit, no matter if this was Poznan or Warsaw." Yet the same interviewee believed Poznań was probably first, because of its many contacts with the West and a tradition of the Abstainers clubs. On the other hand, Warsaw-as the capital city-was more important, also because it had people like Wiktor Osiatyński, a university professor with an international reputation who functioned as a link between Poland and the American AA, and Dr. Bohdan Woronowicz, who tried to help alcoholics in his clinic seeing the ineffectiveness of earlier methods.

In the case of the Polish AA it is therefore difficult to pinpoint a single event which could be described as a mythical moment of the movement's inception, similar to the meeting of Bill W. and Doctor Bob which functions as the American founding myth. This may be a consequence of the above mentioned dualism in the myth of origins of the Polish AA, but it also illustrates the fact that in Poland, AA was a foreign borrowing. It is, on the other hand, possible to find analogies for the Poznan-Warsaw dualism at 
the beginning of the Polish AA movement, and a similar rivalry between Akron, Ohio and New York, which significantly affected the early period of AA in the U.S. (Kurtz). In both cases, this rivalry functioned on several levels related to ambition, personal experience, organizational structure (the center vs. peripheries) as well as the program itself. However, one event seems to reappear consistently in all interviews, symbolically reconciling both centers and both narratives, and it is the 1981 visit in Poznan paid by a group of therapists and founding fathers from Warsaw.

To identify this meeting as the foundation myth of the Polish AA would be an overstatement compared to the symbolic power which the Akron meeting of Bill W. and Doctor Bob represents for the history of AA, though it seems the best choice one has while looking for a single moment of the Polish AA's inception. A comparison of both founding moments brings to mind an intriguing set of similarities and differences.

Similarities:

- A meeting of people from two competing centers

- Venue: a peripheral center

- The meeting does not put the animosities between the two centers to an end, however it does prevent a major split

- The meeting is of vital consequence in the history of the movement

Differences:

- The meeting of two individuals in Akron vs. a meeting of a group of people in Poznan

- A strictly private nature of the meeting in Akron vs. institutional involvement in Poznan

- No professionals in Akron vs. involvement of therapists in Poznan

- Before Akron, there had not been any AA groups; however, there had been AA groups in Poznan and in other places before the meeting in Poznan.

Even though the Poznan meeting is usually identified as the beginning of the unification and of a dynamic development of the Polish AA, the beginnings of the 12step movement in Poland go back to 1948, when when Henryk ZajĄczkowski, Ph.D., M.D. who had previously operated a detox sanitarium in Świack Wołłowiczkowski, initially called "a hospital for men suffering from nervousness-related illnesses" (Tadeusz AA 31), set up a Mutual Help Center for the Sick (Koło Samopomocy Chorych) drawing on his knowledge of the AA rules (Kaczmarczyk 67). In 1950, the first Abstainers Club was established in Poznan. It should be emphasized at this point that the story of the Abstainers Clubs-associations fully controlled by the communist authorities and having a structure typical for organizations of this kind with a formal management board, member IDs etc.-is by no means the story of a grass-roots mutual help organization which AA has always been, also in Poland. Yet the case of the Abstainers Clubs is remarkable in the sense that their establishment and operation was motivated politically, to meet the challenge from the American AA. In 1963, also in Poznan, the psychologist Maria Grabowska, M.A. initiated the meetings of the "Wednesday Group" composed of patients of the local counseling center and members of the Abstainers Club. In 1964, the Group applied for membership with the General Service Office in New York as the first group from behind the Iron Curtain and was subsequently listed in the world register of AA fellowships. Later on, in 1974, the Poznan Wednesday Group transformed into an independent (i.e. free from therapist oversight) and fully self-governed group called "Eleusis." It was the first Polish group 
with direct links to the AA, although in terms of its organization it was still not fully in line with AA's core paradigm (Tadeusz AA 74).

In Poland, the idea of AA had already been popularized by Professor Zbigniew T. Wierzbicki, a social entrepreneur and sociologist, publisher of the Trzeźwość (Sobriety) magazine (since 1956) and Zdrowie i Trzeźwość (Health and Sobriety, since 1957). In 1957, the latter magazine featured his own article on AA, followed in 1958 by a series of texts dealing with AA containing, among other things, the first Polish translation of The Twelve Traditions of Alcoholics Anonymous (Wierzbicki). Yet, the publication of a translation of the 12 Steps was prevented by the censorship office. According to some sources, as early as 1957 the first AA groups based on the ideas championed by professor Wierzbicki were formed, initially in Poznan and subsequently in Warsaw. Still, the historically important Poznan origins of the AA movement had a limited reach (only five more fellowships had been formed up to 1980). The 1980s, however, mark a turning point in the development of the Polish AA with the formation of AA groups in Warsaw. Here again, the key role was played by professional therapists and academics with ties to the fellowship and sharing a concern with the problem of alcoholism. In the 1970s, the psychiatrist Bohdan Woronowicz, M.D., started his therapeutic activity under the auspices of the Institute of Psychiatrics and Neurology. Initially, as he recounts, he did not know much about the AA, but intuition told him to pursue the idea of putting to use the mutual help groups (interview with Bohdan Woronowicz, Warsaw, February 2017). The beginning of the AA in Warsaw is currently considered to be May 1980, because of the establishment of the Odrodzenie (Rebirth) group whose meetings were held in Dr. Woronowicz's ward (Woronowicz). The latter event was preceded, however, by the already mentioned meeting of therapists and alcoholics anonymous from Poznan, Warsaw, and other places throughout Poland which conducted celebrations of the thirtieth anniversary of the Poznan Abstainers Club. Irrespectively of the entire official backdrop and somewhat contrary to the intentions of the officials present at the occasion it became, according to the testimonials of the participants (interviews with FD and Bohdan Woronowicz) and the historians of the movement (Tadeusz AA, Kurtz), another milestone in the grassroots development of the Polish AA -an idea imported from America, which the Communist authorities believed was hard to control.

\subsection{The Polish AA: Its Fast-Paced Growth, Barriers and the Polish Specificity}

The year 1980 marks the beginning of a turbulent period in the history of the Polish AA, which was unique to the Soviet-controlled part of Europe and-according to some historians-worldwide. What allowed the Polish AA to survive through this difficult period was the active role of such individuals as Professor Wierzbicki, Robert Gamblean American pastor, social activist and publisher, and Professor Wiktor Osiatyński, famous for his extraordinary commitment to the development of the AA in Poland in the 1980s. Robert Gamble, who first visited Poland in the 1950s, returned to Poland in 1985 and quickly put his organizational talents into action, getting involved in the movement he knew from the U.S. Beginning in 1985 Wiktor Osiatyński, an internationally recognized lawyer specializing in constitutional law, acted as an intermediary in the communication between the New York headquarters and the GSO and became fully involved in a translation project of the core AA literature. Osiatyński 
also became the first public figure in Poland to "come out" as an alcoholic in the famous article entitled "Grzech czy choroba" ("A Sin or a Disease") published in the Polityka weekly in 1985.

Earlier, in October 1984, the First National AA Rally took place in Poznan with representatives of as many as 34 different groups participating. During the second rally in Zawiercie in 1988, their number grew to 100 (though the actual number is still a matter of discussion among historians) and the third one, organized in Wrocław, gathered representatives of 200 groups. The late 1980s, which could be seen as a second birth of AA in Poland, brought an unrestrained activity, if not an explosion, of AA groups following the fall of communism in 1989. The 1990s saw the publication of the first authorized translation of the AA "Bible" into Polish, followed by a dynamic development of AA literature, the launching of a foundation for coordinating the publishing effort and other organizational activities relevant for the movement, as well as-following the American example-the establishment of the National Service Office (Biuro Służby Krajowej). By the end of the decade the number of AA groups had grown to 1500 .

To summarize this brief presentation of the origins of the Polish AA, one should note that they took place in communist Poland, a country with an authoritarian regime and a bureaucratic practice of exercising power originating from a totalitarian ideology. It was not a coincidence that the years 1957 and 1980-milestones in the Polish AA's history, corresponded with the major turning points of the post-WWII Polish history: the thaw of 1956 and the 1980 visit of John Paul II and the birth of the first Solidarity movement. The latter two events are visibly present in the interviews with the founders of the Polish AA. Yet, this periodization should be accepted with a grain of salt: it is possible that the respondents-consciously or not-incorporated the "big" national events into their narrative to fit it into a larger historical paradigm. The researchers and historians of the movement could, in turn, be affected by something that Mr. Marc Bloch, a famous French historian from the Annales school, called "a fetish of genesis" (Bloch).

\subsection{The Polish AA Movement at the Beginning of the Twenty-First Century}

How popular is the AA movement in Poland today remains a separate issue. Because AA is not an organization and it has no use for formal membership, it is impossible to precisely establish the number of its members. Besides, the lack of formal membership in AA corresponds with the fuzziness of the boundaries between the social worlds described by such theorists as Glaser and Strauss or Konecki and Chomczyński. The problem of this fluidity has always been a difficult issue for the American researchers of the movement in the US (Kurtz), even though they do not use the conceptual apparatus of qualitative sociology. Based on ordinary participation levels in the meetings, which in Poland was on average 10-20 people according to a survey by Ireneusz Kaczmarczyk (106), it would be possible to roughly estimate that every week the meetings across the country were attended by about 10,000 to 30,000 participants. The total number of addicts who were involved in the movement at some point in time and have identified themselves as alcoholics anonymous, but do not actually attend the meetings any more, must be significantly greater. 

movement which is now reaching smaller centers (cf. tables with sociological data in Kaczmarczyk 103-108). One should also note the recent trend of developing cooperation between the AA movement and professional therapeutic services, which are increasingly confident about implementing elements of group therapy along with the Minnesota method, created in the U.S. and based on the 12-step program. What makes this change significant is a shift in thinking about alcoholism, which is increasingly perceived as a disease, without carrying the social stigma that accompanied it before. Another important aspect of this change is the discontinuation of using medications like Anticol, Antabus or Esperal. One should also note the growing interest in the first private-sector centers for addiction therapy (like Warsaw-based Olcha or Akmed). Those centers work entirely based on the 12-step program and offer not only out-patient services but also in-house treatment with a 28-day stay based on the Minnesota method used by their American counterparts (interview with MZ, January 2017, interview with HP, Gdansk, March 2017, interview with IL, Warsaw, November 2017, interview with TP, Warsaw, December 2018). Nowadays, whether it is a detox ward in a hospital, a public or private-sector service, it has become a standard practice to encourage patients to attend AA meetings. Such an embedding of an essentially grass-roots movement like AA into an organized system of therapeutic services testifies to the AA fellowship's growing recognition, but at the same time gives rise to numerous controversies (interview with WD, DĄbrowĄ Górnicza, June 2018, interviews with TT and Bohdan Woronowicz). It will be worthwhile to take a close look at these as they might draw interesting analogies with the development of the American AA fellowship (Kurtz, Peele and Brodsky, Wuthnow), and could shed more light on the issue of the Polonization of AA as an American phenomenon.

The above discussion of the spread of AA in Poland may hopefully serve to confirm the view expressed by Klaus Makela in his introduction to the study authored by a team of international researchers that the Alcoholics Anonymous is "one of the big success stories" of the twentieth century (Makela 3). Obviously this success, more than anything else, is the success of every recovered alcoholic gathered in one of the thousands autonomous groups in over 180 countries and territories across the globe. But this organizational success was also made possible through an effective use and adaptation of the movement's values rooted in the specific American cultural and social traditions.

\section{BIBLIOGRAPHY}

Abherd, Denise. "Ideology, Melodrama, and the Changing Role of Alcohol Problems in American Films." Contemporary Drug Problems 13 (1986). Print.

Alcoholics Anonymous (“The Big Book”). 1939. New York: Alcoholics Anonymous Publishing, 2001. eBook. 
Alcoholics Anonymous Comes of Age. A Brief History of A.A. 1957. New York: Alcoholics Anonymous Publishing, 1985. eBook.

Alcoholics Anonymous founding document sells for \$2.4M [in:] „AP News.” https://www.apnews.com/ fb86fe68345944fe8c21fd7263c44f37/Alcoholics-Anonymous-founding-document-sells-for-\$2.4M, (June 2018).

Bellah, Robert N., Richard Madsen, William M. Sullivan et al. Habits of the Heart: Individualism and Commitment in American Life. Berkley: University of California Press, 2007. Print.

Bloch, Marc. Pochwała historii. Wanda Jedlicka and Hubert Łukasiewicz. Warszawa: PWN, 1962. Print.

Bufe, Charles, and Peele, Stanton. Alcoholics Anonymous: Cult or Cure? Tucson: See Sharp Press, 1997. eBook.

Cornes, Judy. Alcohol in the Movies, 1898-1962: A Critical History. Jefferson, N.C.: McFarland, 2006. Print.

Dick B. Why Early A.A. Succeeded. Kihei, Maui, Hawaii: Paradise Research Publications, 2001. eBook. Dumanowski, Feliks. Zgrabki i niezgrabione. Warszawa: Raj Media, 2015. Print.

Glaser, Barney, and Strauss, Anselm. The Discovery of Grounded Theory: Strategies for Qualitative Research. New Brunswick: Aldine Transaction, 1999. Print.

Hurvitz, Nathan. “The Origins of the Peer Self-Help Psychotherapy Group Movement.” Journal of Applied Behavioral Science 12 (1976) 283-294. Print.

James, William. The Varieties of Religious Experience: A Study in Human Nature, Being the Gifford Lectures on Natural Religion Delivered at Edinburgh in 1901-1902. New York, London, 1902. eBook.

Józef Jan alkoholik. Jestem alkoholikiem. Świadectwa AA. Warszawa: W drodze, 1999. Print.

Kaczmarczyk, Ireneusz. Wspólnota Anonimowych Alkoholików w Polsce. Alkoholowe dno i co to znaczy trzeźwieć. Warszawa: Eneteia, 2008. Print.

Konecki, Krzysztof T. Studia z metodologii badań jakościowych. Teoria ugruntowana. Warszawa: Wydawnictwo Naukowe PWN, 2000. Print.

Konecki, Krzysztof T., and Piotr Chomczyński. Słownik socjologii jakościowej. Warszawa: Difin, 2012. Print.

Kurtz, Ernest. Not God: A History of Alcoholics Anonymous. Hazelden 2010. eBook.

Lipset, Seymour M. American Exceptionalism: A Double-Edged Sword. New York and London: W. W. Norton, 1997. Print.

Makela, Klaus. Alcoholics Anonymous As A Mutual-Help: A Study In Eight Societies, Madison: University of Wisconsin Press, 1996. Print.

Maziarski, Wojciech. Jak feniks z butelki. Rozmowy z alkoholikami. Warszawa: Waza, 2013. Print.

Meszuge. Alkoholik. Autobiograficzna opowieść o życiu, piciu, uzależnieniu i wyzwoleniu. Warszawa: WAM, 2011. Print.

Osiatyński, Wiktor. Alkoholizm: grzech czy choroba? Warszawa: Iskry, 2005. Print.

---. “Grzech czy choroba.” Polityka 51 (1985). Print.

Peele, Stanton, and Archie Brodsky. The Truth About Addiction and Recovery. New York: Simon \& Schuster, 1991. eBook. 
Putnam, Robert D. Bowling Alone: The Collapse and Revival of American Community. New York. Simon \& Schuster, 2001. Print.

Room, Robin. "Alcoholism and Alcoholics Anonymous in US Films, 1945-1962: The Party Ends for the "Wet Generations." Journal of Studies on Alcohol 50.4 (1989). Print.

Snella-Mrozik, Bożena. Piekło nie ma dna: Rozmowy z trzeźwymi alkoholiczkami. Poznań: Media Rodzina, 2009. Print.

Strauss, Anselm. L., and David Maines. Continual Permutations of Action. New Brunswick: Aldine Transaction, 2009. Print.

Tadeusz AA. Historia AA w Polsce. Vol. I. Warszawa: Fundacja Biuro Służby Krajowej Anonimowych Alkoholików w Polsce, 2012

Twelve steps and Twelve Traditions. 1953. New York: Alcoholics Anonymous Publishing, 1985. eBook Wierzbicki, Zbigniew T. “Dwanaście Tradycji AA.” Zdrowie i Trzeźwość (1958). Print.

Woronowicz, Bohdan. Dasz radę! O pokonywaniu uzależnień, Warszawa: Prószyński, 2014. Print.

Wuthnow, Robert. Sharing the Journey: Support Groups and the Quest for a New Community. New York: Free Press, 1996. eBook.

Ziółkowski, Marek. “Wprowadzenie do wydania polskiego.” Robert D. Putnam. Samotna gra w krĘgle. Trans. Przemysław Sadura and Sebastian Szymański. Warszawa: Wydawnictwa Akademickie i Profesjonalna, 2008. Print.

\section{NOTES}

1. Significantly all the three features depicted above: religiousness, individualism and pragmatism are noted as peculiar for America in the perception of non-American AA members and students of the subject (cf. Makela; Tadeusz AA; Osiatyński; interviews conducted by myself).

2. In 2015-2018, I conducted eighteen in-depth interviews. The respondents can be divided into three general groups: (1) "the AA founding fathers" and friends of the fellowship; (2) longstanding AA fellows and people involved in the so-called AA services; (3) therapists who use the Minnesota method which is based on the AA ideas. The analysis of those interviews constitutes the basis of a more extended research effort described above. For the purposes of this article, only some of those interviews were used. When a respondent was a commonly recognized person, not as a fellow-alcoholic in the movement, his full name and the date are provided. In other situations, in line with the rule of anonymity, the fellows are referred to by their initials and the date and place of the interview. Certain details concerning the interviewees are presented below: FD-a long-standing fellow-alcoholic, one of the founders of AA in Warsaw, an over-seventy man; HF-a long-standing fellow-alcoholic, involved in the AA services in Gdansk, an over-sixty man; IL-an alcoholic with a long period of sobriety, with experience as an AA fellow and in group therapy, an over-fifty woman; MZ-a therapist from a leading Warsaw help center, a fellow-alcoholic, an over-fifty woman; TF-a long-standing AA fellow, credited for his efforts in Lesser Poland, an over-sixty man; TT-a long-standing AA fellow, pro-active member of the AA services in Poznan, credited for his involvement in the development of AA in the Greater Poland, an AA historian; TP-a therapist from a leading Warsaw center, an AA fellow, an overfifty man; WD-a social activist, a member of the Abstainers movement (board member) from the Upper Silesia and also an AA fellow, an over-seventy man. 


\section{ABSTRACTS}

The goal of this article is primarily to present a historical outline of the origins of the Polish AA, supplemented with general reflections on the 12-step fellowships and their "American" specificity, as well as the challenges posed by their adaptation to a different cultural context. Indepth interviews used in my research, complemented by cultural sources and fellow-alcoholics' publications on the history of the community in Poland make it possible to close the gap that has persisted in the AA research. They indicate the social and cultural aspects of the spread of the 12steps movements, which so far have not been studied directly, since the research has mainly dealt with the therapeutic side of the issue. Moreover, including the Polish perspective might add new threads to the debate on the U.S. cultural influence abroad.

\section{INDEX}

Keywords: Alcoholics Anonymous, American influences, alcoholism, cultural adaptations, therapy, 12-steps movements

\section{AUTHOR}

\section{MAREK JANNASZ}

Marek Jannasz received his M.A. in History and worked as a researcher at the University of Warsaw's American Studies Centre. He was also a Fulbright Scholar at Indiana University (1997). He became a publisher and a co-founder of two Warsaw-based publishing houses: Lingo (education, references, multimedia) and Lira (fiction, biographies). He is now a doctoral candidate in cultural studies at the SWPS University in Warsaw, and is writing his Ph.D. dissertation on the 12-steps movements, focusing on AA as a social and cultural phenomenon. 